\title{
An Acoustic and Perceptual Analysis of Vowels Preceding Final /-s/ Deletion in the Speech of Granada, Spain and Cartagena, Colombia
}

\author{
Miguel A. Rincón ${ }^{1}$ \\ Bellarmine University, EE.UU.
}

\begin{abstract}
This study sets out to verify the claim that the tense-lax alternation undergone by vowels preceding deletion of post-nuclear /s/ in Eastern Andalusian Spanish may serve as a functional marker when distinguishing singular from plural in nouns rendered homophonous by the deletion of final /-s/, e.g. calle ['ka.je] 'street' vs. calles ['ka.jcØ] 'streets.' Samples from Granada Spanish speakers revealed a significant opening for the vowels with deleted final /-s/. In a subsequent speech perception test, speakers were prompted with stimuli and determine whether they heard the singular form calle ['ka.je] with the closed allophone or the plural form calles [' $k a . j \varepsilon \emptyset]$ with the open allophone. Results reveal that, despite the significant vocalic alternation, participants were unable to consistently identify between singular and plural forms based solely on the open and closed allophonic contrast. With the purpose of establishing a cross dialectal comparison, both the vowel analysis and perception test
\end{abstract}

\footnotetext{
1 Para correspondencia, dirigirse a: Miguel A. Rincón (mrincon@bellarmine.edu), Departamento de Lenguas y Culturas Extranjeras, Bellarmine University, 2001 Newburg Road, Louisville, Kentucky, EEUU 40205.
} 
were replicated with native speakers of Cartagena, Colombia, and similar results were obtained.

Keywords: vowel alternation, vowel centralization, open vowel allophones, vowel space.

\section{ANÁLISIS ACÚSTICO Y PERCEPTIVO DE LAS VOCALES QUE PRECEDEN ELISIÓN DE /-S/ FINAL EN LAS HABLAS DE GRANADA, ESPAÑA Y CARTAGENA COLOMBIA}

\section{Resumen}

El presente estudio investiga la hipótesis de que el desdoblamiento vocálico o la alternancia tensa laxa de las vocales que preceden elisión de /s/ posnuclear en el español de Andalucía Oriental tiene una función que permite distinguir entre el singular y el plural con formas homófonas debido a la pérdida de /s/ final, por ejemplo, calle ['ka.je] vs. calles ['ka.jeØ]. Un análisis acústico con muestras tomadas de hablantes nativos de español de Granada reveló una apertura significativa para aquellas vocales que preceden elisión de /s/ final. En una subsiguiente prueba de percepción, los participantes escuchaban el estímulo y debían determinar si escuchaban la forma singular calle ['ka.je] con el alófono cerrado o si escuchaban la forma plural calles ['ka.jeØ] con el alófono abierto. Los resultados muestran que, a pesar de la significativa apertura vocálica, los participantes no podían identificar consistentemente entre las formas singulares y plurales basados en el contraste entre alófonos abiertos o cerrados. Del mismo modo, con el propósito de establecer una comparación dialectal, el análisis acústico y la prueba de percepción se replicaron con hablantes nativos de español de Cartagena, Colombia, donde se obtuvieron resultados similares.

Palabras clave: alternancia vocálica, centralización, alófonos abiertos, espacio vocálico.

Recibido: 11/01/17 Aceptado: 30/04/18 


\section{INTRODUCTION}

This study is motivated on the grounds that final/-s/ deletion, a purported characteristic feature of Andalusian Spanish, has induced vowel restructuring. Navarro Tomás (1939) claimed that in the Andalusian variety of Spanish the vowels adjacent to a deleted /s/ assume a more open articulation and also appear to be lengthened. This vocalic feature has led some linguists to propose a vocalic system comprised of ten or eight vowels (Alvar 1955, Alarcos Llorach 1958). Consequently, a publication in the Atlas Lingüístico y Etnográfico de Andalucía (ALEA) allowed the circumscription of the phenomenon of vocalic laxing or opening in the eastern Andalusia region (Mondéjar 1970).

In Standard Spanish final /s/ often fulfills two grammatical functions; it marks the second singular person ves 'you see' versus third person singular $v e$ 'he/she sees' in most verbal paradigms and it indicates the plural form of nouns and adjectives (casa 'house' versus casas 'houses' and alto 'high' (singular) versus altos 'high' (plural)). This purported vowel alternation is said to have a semantic value in Andalusian Spanish in which speakers can distinguish, apart from context, when a final $/ \mathrm{s} /$ has been deleted. In other words, speakers of eastern Andalusian would thus be able to differentiate between second and third person verb forms in most paradigms as well as to distinguish singular from plural forms in nouns and adjectives based on the quality of the vowel. This purported differentiation between second and third person verb forms appears to be limited to situations in which final $/$-s/ is the only indicator of the grammatical person within a sentence. Any other contextual marker appearing within a sentence would yield vocalic opening redundant.

The first studies carried out on Andalusian vowel restructuring were of an impressionistic nature and lacked experimental verification (Mondéjar 1970; Salvador 1977; López Morales 1984). More recent studies on eastern Andalusian vowel alternation, however, show conflicting results, differing methodological choices and data-collection procedures for elicitation tasks. Martínez Melgar (1986) did not find differences in vowel quality in word-final plural forms preceding deleted /s/. However, she points out that participants in her study were from towns in western Jaén and Córdoba and this area falls within the borders of diglossia that divides eastern Andalusian from western Andalusian Spanish. In a subsequent study, Martínez Melgar (1994) included participants from the provinces of Granada, Almería as well as eastern Jaén. This time the author found a systematic opening of the mid vowels /e/ and /o/. The opening of the mid vowels found by Martinez 
Melgar concurs with the findings reported by Llisterri and Poch (1987) and by Sanders (1994). The study conducted by Sanders (1994), however, only employed samples from three Granada college students. None of these studies offered perceptual tests to verify the alleged distinctive value of vowel alternation in eastern Andalusia. Carlson's (2006) speech samples employed three participants from eastern Andalusia and three from western Andalusia. Carlson's (2006) perception tests employed 25 participants of which 23 were from western Andalusia. This factor is methodologically problematic because the quality of the vowels in the eastern Andalusian dialect has been claimed to be markedly different than those in the western Andalusian dialect.

One of the objectives of the present study is to investigate whether speakers of eastern Andalusian Spanish, particularly from the dialect of Granada, are able to recognize vowels that precede deleted post-nuclear/-s/ from those that are not based on a vowel alternation. This study also aims to provide acoustic measurements of vowels preceding final /-s/ deletion from samples taken from speakers of Granada Spanish under two types of tasks, a sociolinguistic interview and an elicitation task. With the purpose of providing cross-dialectal insight, speech samples of the Spanish spoken in Cartagena, Colombia, were also included and tested in this study. Like Granada Spanish, Cartagena Spanish is well-known for its high rate of final /-s/ elision (Becerra 1985) ${ }^{2}$. Thus, the comparison between Granada Spanish and Cartagena Spanish is intended to provide a more in-depth insight about the potential processes affecting the vowels that precede final/-s/deletion.

\section{ACOUSTIC ANALYSIS}

\subsection{Methodology}

The speech samples under analysis were obtained from ten subjects from Granada and ten subjects from Cartagena. The acoustic analysis of this study will be guided by the following research questions:

2 The inclusion of this non-conservative Spanish dialect was motivated by a logistical decision. Given that he researcher is from Colombia, it was much easier to collect data from this Caribbean city. 
1. Do vowels in both Granada and Cartagena dialects undergo significant formant restructuring when preceding deleted final /-s/?

2. Does the type of task employed during data collection (e.g. interview or elicitation) significantly affect the formant structure of vowels that precede deleted final /-s/ in both Cartagena and Granada dialects?

The speech samples analyzed in this acoustic study were taken from ten native speakers of Granada Spanish (five female and five male students) and ten native speakers of Cartagena Spanish (five female and five male students). Overall, the analysis will follow a similar methodology to that of Hammond (1978), Figueroa (2000) and Carlson (2006). However, unlike the first two studies that employed bilingual participants, only Spanish monolingual speakers participated in this analysis. We believe that the use of monolingual participants in an acoustic and perception study is essential. For instance, Ronquest (2012) argues that the vowel space in Spanish monolinguals is larger than the vowel space in bilinguals.

The Granada participants are students from the University of Granada in Granada, Spain and the Cartagena participants are students from the Universidad de Cartagena in Cartagena, Colombia. These participants shared similar criteria as the participants in the perception study. That is, they are college students from public universities and range in age from 20-25 years ${ }^{3}$. These criteria seek to control variables such as age, social class and education level among the participants and ensure the homogeneity of the linguistic sample under analysis.

The following section describes the procedure followed in this study to obtain speech samples for the acoustic analysis. With the purpose of obtaining spontaneous oral production, this study analyzes speech samples obtained in a sociolinguistic interview task. Thus, in the sociolinguistic interview task participants were prompted with free topic questions such as follows:

1. How do you like your major?

2. How could the (major) program be improved?

\footnotetext{
3 Traditionally higher education in Colombia has been for wealthy or higher classes. Nowadays, upper-class families prefer to send their children to study in private universities or away to larger cities where universities enjoy a higher prestige. The only three public universities in Colombia in the Caribbean region are the University of Atlántico (Universidad del Atlántico) in Barranquilla, the University of Magdalena (Universidad de Magdalena) in Santa Marta and the University of Cartagena (Universidad de Cartagena) in Cartagena. Thus, the University of Cartagena has become a frequent choice for middle class students from Cartagena and nearby areas.
} 
3. What activities do you recommend a tourist who is visiting this city?

4. How do young people spend their free time in this city?

The use of this type of question is recommended since it is believed they engage speakers into storytelling mode and encourage them to produce vernacular features (Labov 1984). Each interview lasted approximately 7 minutes. In addition to the speech samples obtained in the sociolinguistic interview task, speech samples were also obtained via elicitation. Two sets of test sentences, Form A and Form B, were used to elicit allophonic variants of /s/ in three environments: syllable-final position within a word; wordfinal position within a breath-group; and utterance-final position. These two sets of sentences provide words that contrast with each other according to the presence or absence of the phoneme $/ \mathrm{s} /$ in the environments stated. For instance, on Form A, test sentence 5 reads: Es cierto que lo busca "It's true that s/he's looking for him," while on Form B, test sentence 5 read: Es cierto que lo buscas "It's true that you're looking for him." In order to ensure a natural rhythm of speech, each participant was given one card at a time and instructed to read the sentence on it and memorize it. Once the sentence was memorized, the participant said it out loud. Each participant had approximately 10 seconds to memorize the sentence before saying it. This procedure was done with a first set of sentences (Form A) and was repeated with a second set of sentences (Form B) two days later to avoid recency effects. Speech samples were recorded with a Marantz PMD660 Digital Recorder in a quiet location to minimize ambient interference.

Acoustically, vowel quality can be measured in terms of formant frequencies. Formants are acoustic resonances which are the result of different configurations of the vocal tract (Ladefoged 2001). Vowels have several formants of which the first three are the most important for speech perception. The values of these formants differ from vowel to vowel; however, they constitute an objective way to measure and analyze vowels. The first formant (F1) corresponds inversely to the height dimensions of a vowel. High vowels have a low first formant (F1) and low vowels have a high F1. Similarly, the second formant (F2) is correlated with the advancement (front/back) of the tongue. Front vowels have a high F2 and back vowels have a low F2 (Johnson 2003). Nowadays the best way to describe vowels is by conducting acoustic analyses of a group of speakers and specifying their mean formant frequencies (Ladefoged 2001). To this end, vowel formant and vowel length measurements were taken for the vowels obtained from the samples of the sociolinguistic interview and elicitation task. These target words feature the absence or presence of syllable-final or word-final /s/ (e.g. foto 'picture' vs fotos 'pictures,' pecado 'sin' versus pescado 'fish.' 
A combined total of 7,872 tokens were obtained from the sociolinguistic interview and the elicitation task.

The 'Praat' program (Boersma and Weenink 2014) was utilized for the acoustic analysis, in which token vowels were labeled with a six-character code in a one-tier script. The word ves 'you see' is shown in Figure 1 (Appendix A) with the purpose of illustrating the labeling. This word was extracted from the target sentence Creo que la ves 'I think he/she sees it.' The label ves-lghp0e indicates that the vowel /e/in the word ves was uttered by a male from Granada in the elicitation task. It also indicates that this vowel occurs in utterance-final position and the final /s/ was deleted.

The data obtained from the Granada and Cartagena participants were subjected to statistical analysis. A t-test was selected in order to test the statistical significance of a possible vocalic alternation or formant opening or lengthening of vowels preceding $/ \mathrm{s} /$ deletion. The t-test compares the means between two groups: vowels followed by the deleted post-nuclear/s/ and vowels without a following final/-s/. Recall that for this study vowels were segmented and labeled with a six-character code, where ' 0 ' refers to vowels that precede deleted /s/ e.g., ves [beØ] 'you (sg) see' whereas ' 3 ' refers to vowels without final/-s/, e.g., ve [be] 'he/she sees.' For the ease of explanation, henceforth ' 0 ' refers to a vowel preceding deleted final/-s/ and ' 3 ' refers to a vowel without a following final /-s/.

Consequently, in order to test whether vowels are significantly more open when preceding a deleted $/ \mathrm{s} /$, the t-test will compare $\mathrm{F} 1$ normalized values for vowels in ' 0 ' versus vowels in ' 3 '. Thus, the independent variable is 'group 0 and 3 ' and the dependent variable is normalized F1 (henceforth $|\mathrm{F} 1|$ ).

In addition, in order to compare whether vowels are significantly more fronted, less fronted or centralized when preceding deleted $/ \mathrm{s} /$, the t-test will compare F2 normalized for vowels in ' 0 ' and vowels in ' 3 '. The independent variable is 'group 0 and ' 3 ' and the dependent variable is normalized F2 (henceforth $|\mathrm{F} 2|)$.

In the same vein, in order to compare whether vowels lengthen significantly when preceding deleted $/ \mathrm{s} /$, the t-test will compare normalized vowel length in ' 0 ' and in ' 3 .' The independent variable is 'group 0 and $3^{\prime}$ ' and the dependent variable is normalized duration (henceforth |DUR|). Statistical analyses were performed via MATLAB (2011). Thus, independent $t$-tests were conducted on each vowel to test vowel alternation and vowel lengthening according to dialect (Granada/Cartagena), type of task (elicitation/interview), and linguistic context (syllable-final/word-final/ utterance-final). In order to cancel out the acoustic variance provided by non-target dimensions, formant values were normalized according to the following criteria: 
- For dialect analyses, vowels were normalized for subject, task, and linguistic context.

- For task analyses, vowels were normalized for subject, dialect and linguistic context.

- For linguistic context analyses, vowels were normalized for subject, dialect, and task.

\subsection{RESULTS FOR EFFECT OF DIALECT ON VOWEL ALTERNATION}

\subsubsection{Granada dialect}

T-test results for vowels in Granada reveal that for:

- Vowel /a/: $|\mathrm{F} 1|$ in ' 0 ' $($ mean $=567 \mathrm{~Hz})$ is significantly lower than $|\mathrm{F} 1|$ in ' 3 ' $($ mean $=584 \mathrm{~Hz})(\mathrm{t} 1154=-3.93, \mathrm{p}<0.001)$. This indicates that the vowel /a/ is less open when preceding deleted /s/. No significant results for $|\mathrm{F} 2|$ in ' 0 ' were found.

- Vowel /e/: $|\mathrm{F} 1|$ in ' 0 ' (mean $=407 \mathrm{~Hz})$ is significantly higher than $|\mathrm{F} 1|$ in ' 3 ' ( $($ mean $=388 \mathrm{~Hz})(\mathrm{t} 815=2.18, \mathrm{p}=0.002)$. This indicates that the vowel /e/ is more open when preceding deleted /s/. |F2| in ' 0 ' (mean $=1922$ $\mathrm{Hz}$ ) is significantly lower than $|\mathrm{F} 2|$ in ' 3 ' (mean $=2128 \mathrm{~Hz})(\mathrm{t} 815=-7.88$, $\mathrm{p}<0.001)$. This indicates that vowel $/ \mathrm{e} /$ is less fronted or centralized when preceding deleted $/ \mathrm{s} /$.

- Vowel /i/: No significant results for $|\mathrm{F} 1|$ were found. $|\mathrm{F} 2|$ in ' 0 ' $($ mean $=2161 \mathrm{~Hz})$ is significantly lower than $|\mathrm{F} 2|$ in ' 3 ' (mean $=2274 \mathrm{~Hz})$ ( $\mathrm{t} 273=-3.06), \mathrm{p}=0.002$. This indicates that $/ \mathrm{i} /$ is less fronted or centralized when preceding deleted $/ \mathrm{s} /$.

- Vowel /o/: No significant results were found for either $|\mathrm{F} 1|$ or $|\mathrm{F} 2|$ when $/ \mathrm{o} /$ precedes deleted $/ \mathrm{s} /$.

- Vowel /u/: As in the case of /o/, no significant results were found for the vowel $/ \mathrm{u} /$ regarding formant alternation in $|\mathrm{F} 1|$ nor $|\mathrm{F} 2|$ when the post-nuclear $/ \mathrm{s} /$ is deleted.

In summary, in Granada Spanish the vowel /e/ becomes more open and centralized when the following $/ \mathrm{s} /$ is deleted. It should be noted that the results regarding the F1 and F2 alternation for vowel /e/ in Granada concur with the results reported in Llisterri and Poch (1987), Sanders (1994), and Martínez Melgar (1994). The vowel $/ \mathrm{i} /$ is less fronted when preceding deleted /s/. These results for F2 also concur with those reported by Sanders (1994) and Martínez Melgar (1994). 
Regarding question number 1, a t-test was used to compare the formant value means between vowels preceding deleted final/-s/ and vowels without a following /s/. Results reveal a myriad of significant vowel formant restructuring, particularly for non-high vowels when preceding deleted final /-s/. In Granada Spanish, the vowel [a] is significantly less open when preceding deleted final/-s/. The vowel [e] is significantly more open and more centralized in Granada Spanish. The vowel [i] is significantly more centralized in Granada Spanish. It should be noted that the high vowels /i/ and $/ \mathrm{u} /$ preceding deleted word-final /-s/ appear throughout our data, for the most part, in the determiners mis 'my,' tus 'your,' and sus 'his/her.' The vowel $/ \mathrm{i}$ / preceding deleted final/-s/ occurs in utterance-final position in only two nouns taxis 'taxis' and tenis 'tennis.' These words appear at the end of sentence \# 3 ¿No te gusta jugar al tenis? 'Don't you like to play tennis?' and target sentence \# 37 Esos hombres se fueron en taxis 'Those men left in taxis.'

The mean values for the formant frequencies of vowels in Granada Spanish have been plotted in Figure 2 (Appendix A) to better illustrate the change in vowel quality for vowels preceding deleted final /-s/. Figure 6.1 clearly shows the decrease of aperture for /a/ and the centralization of /e/ when preceding deleted /s/ in Granada Spanish. For ease of presentation, ' 0 ' in the Figure refers to the vowels that precede deleted final /-s/, whereas ' 3 ' refers to vowels without a following /s/.

\subsubsection{Cartagena dialect}

Regarding Cartagena Spanish, the vowel /a/ is significantly less open when preceding deleted final/-s/, whereas the vowels /e/ and /o/ are significantly more centralized. The formant frequencies for vowels in Cartagena are plotted in Figure 3 (Appendix A) to illustrate the quality change of vowels that precede deleted final/-s/. Figure 3 shows a lesser aperture for $/ \mathrm{a} /$, as well as the centralization of $/ \mathrm{e} /$ and $/ \mathrm{o} /$ when preceding deleted final $/ \mathrm{s} /$.

T-test results for vowels in Cartagena reveal that for:

- Vowel /a/: $|\mathrm{F} 1|$ in ' 0 ' $($ mean $=541 \mathrm{~Hz})$ is significantly lower than $|\mathrm{F} 1|$ in ' 3 ' $($ mean $=590 \mathrm{~Hz})(\mathrm{t} 665=-3.60, \mathrm{p}<0.005)$. This indicates that the vowel $/ \mathrm{a} /$ is less open when preceding deleted $/ \mathrm{s} /$. No significant results were found regarding a possible alternation of $|\mathrm{F} 2|$ for $/ \mathrm{a} /$ when preceding deleted $/ \mathrm{s} /$.

- Vowel/e/: No significant results were found for $|\mathrm{F} 1|$ in ' 0 .' However, $|\mathrm{F} 2|$ in ' 0 ' (mean $=1898 \mathrm{~Hz})$ is significantly lower than $|\mathrm{F} 2|$ in ' 3 ' ( (mean = $2001 \mathrm{~Hz})(\mathrm{t} 548=-2.003, \mathrm{p}<0.005)$. This indicates that the vowel /e/ is less fronted or centralized when following deleted $/ \mathrm{s} /$. 
- $\quad$ Vowel /i/: No significant results were found for $|\mathrm{F} 1|$ nor $|\mathrm{F} 2|$ when /i/ precedes deleted /s/.

- Vowel /o/: No significant alternation for $|\mathrm{F} 1|$ in ' 0 ' was found. $|\mathrm{F} 2|$ in ' 0 ' ( mean $=1256 \mathrm{~Hz})$ is significantly higher than $|\mathrm{F} 2|$ in ' 3 ' ( (mean $=1228$ $\mathrm{Hz})(\mathrm{t} 550=2.49, \mathrm{p}<0.005)$. This indicates that the vowel $/ \mathrm{o} /$ is more fronted or centralized when preceding deleted $/ \mathrm{s} /$.

- Vowel /u/: As in the case of /i/, no significant results were found for $|\mathrm{F} 1|$ nor $|\mathrm{F} 2|$ when $/ \mathrm{u} /$ precedes deleted $/ \mathrm{s} /$.

In summary, in Cartagena vowel /a/ is significantly less open when the following $/ \mathrm{s} /$ is deleted. In addition, the mid-vowels $/ \mathrm{e}, \mathrm{o} /$ centralize when precede deleted $/ \mathrm{s} /$. The mean values for the formant frequencies of vowels in Cartagena Spanish have been plotted in Figure 3 (Appendix A).

\section{PERCEPTION TEST}

\subsection{Methodology}

The perception test is comprised of four sections but only the results from Part I and Part III were used in the final scoring. Likewise, control items in which final $/ \mathrm{s} / \rightarrow[\mathrm{s}]$ were not included in the scoring. Participants scored $100 \%$ in control items. Part I analyzed pairs of complete sentences with and without post-nuclear /s/ in utterance-final position Creo que la ve [kreo\#ke\#la\#ße] 'I think that he sees her' versus Creo que la ves [kreo\#ke\#la\#ßeØ] 'I think that you see her.'2 In turn, Part III analyzed isolated lexical pairs with and without post-nuclear/s/ in word-final position, e.g., calle ['ka.je] 'street' versus calles ['ka.jeØ] 'streets'. All participants completed every question in the perception test, that is, in no instances were there blank entries.

The research questions for the present perception experiment are two:

1. Are participants from both the Granada and Cartagena dialects able to determine the presence or absence at a statistically significant rate of the $[\varnothing]$ allophone of deleted post-nuclear/s/ in final contexts? In other words, are the participants capable of distinguishing pairs of words such as casa ['ka.sa] 'house' and casas ['ka.saØ] 'houses' or calle ['ka.je] 'street' and calles ['ka.jeØ]'streets'? 
2. If participants possess the ability to determine the presence or absence of the $[\varnothing]$ allophone of deleted post-nuclear /s/ in final contexts in pairs of words such as casa ['ka.sa] and casas ['ka.saØ], calle ['ka.je] 'street' and calles ['ka.jeØ]'streets,' pueblo ['pue.blo] 'town' and pueblos ['pue. bloØ] 'towns,' is this ability determined by a particular vowel allophone?

We hypothesize that, as a result of vowel alternation, participants from Granada will be able to readily distinguish between tokens without a following final/-s/and tokens with deleted final/-s/. Therefore, it is expected that the rate of correct responses for tokens without a following final $/ \mathrm{s} /$, e.g., casa ['ka.sa] 'house,' pueblo ['pue.blo] 'town,' will not be significantly different from the rate of correct responses for tokens with deleted final $/ \mathrm{s} /$, e.g., casas ['ka.saØ] 'houses,' pueblos ['pue.bloØ] 'towns.' In other words, if Granada participants make successful use of vowel alternation, they will accurately identify both items without final/-s/ and items with deleted final /-s/, likely due to some sort of compensatory mechanism.

Conversely, as vowel alternation is not regarded as a feature in Cartagena Spanish, we hypothesize that Cartagena participants will not display accuracy when distinguishing between tokens without a following final/-s/ and tokens with deleted final /-s/ in the perception test. In other words, it is expected that Cartagena participants will not accurately distinguish items with deleted final/-s/ as well as items without a following final/-s/. It should be noted that participants in the acoustic study are different from those who participated in the perception test.

The perception test data were subjected to statistical analysis. Given that two samples and their values are obtained from the same participant, that is, each participant provides two values, a value for items without /s/ and another for items with deleted final/s/, a paired-sample t-test is an appropriate test to use. A paired-sample t-test was, therefore, used to determine if the two means of the two values (rate of correct responses for tokens without a following final /-s/ and rate of correct responses for tokens with deleted final /-s/) are different.

For this statistical analysis SPSS (IBM 2012) was utilized and the following procedure was followed: the number of each participant was entered in the first column; the mean of the correct answers for items with deleted final/-s/ was entered in the second column; the mean of the correct answers for items without a following final /-s/ was entered in the third column, and the dialect of each participant (Granada or Cartagena) was entered in the fourth column. 


\subsection{RESULTS}

A paired-sample t-test (see Table 1 in Appendix B) revealed a statistically significant difference between the mean percentage of correct answers for items without final $/-\mathrm{s} /$ and the mean percentage of correct answers for items with deleted final $/$-s/, t (39) $=26.492, \mathrm{p}=<.0001$. These results indicate that both Granada and Cartagena participants are able to accurately identify the items without a following final /-s/ in the perception test (i.e., singular forms of nouns and adjectives and third person singular verb forms. However, participants in both dialects failed to correctly identify items with deleted final /-s/ (i.e., plural forms of nouns and adjectives and second person singular verb forms).

Granada participants identify items without a following final/-s/ (singular nouns and adjectives and third-person singular verb forms) with a rate of $82.3 \%$. Conversely, results indicate that Granada participants are not able to accurately identify the items with deleted final /-s/. They identified items with deleted final /-s/ (plural of nouns and adjectives and second-person singular verb forms) with a rate of $38.45 \%$. Likewise in the Cartagena dialect, participants display a high rate of correct responses when identifying the items without a following final $/ \mathrm{s} /$. Cartagena participants correctly identified items without a following final $/$-s/ with a rate of $89.2 \%$. However, they failed to identify the items with deleted final /-s/ accurately. The percentage of correct responses for items with deleted final /-s/ was $35.57 \%$.

Recall that the second research question of the perception study aimed to determine whether some type of vowel restructuring for /a, e, o/ plays a role in the accurate identification of items with deleted final/-s/in words such as casas ['ka.saØ], calles ['ka.jeØ]'street' and pueblos ['pue.bloØ] 'towns.' An ANOVA test was conducted in order to test the possible effects of the vowel on the accurate identification of deleted final /-s/. Results (Appendix B) show no main effect on the interaction between a specific vowel and the identification of deleted final/-s/. In other words, none of the non-high vowels $[a, e, o]$ is significantly more identifiable than the others.

The overall rate of correct responses for items in which final/-s/ is deleted suggests that neither Granada nor Cartagena participants possess the ability to accurately determine whether the allophone $[\varnothing]$ is present. 


\section{CONCLUSION}

The most important finding of this study, however, is not the occurrence of the tense-lax alternation in vowels that precede deleted final/-s/. The greater interest is the veracity of the claimed distinctive function often attributed to the vocalic alternation in eastern Andalusian Spanish. The claim that the tense-lax vowel alternation in eastern Andalusian Spanish allows speakers to distinguish between vowels with deleted /s/ and vowels without final /s/ was tested. The perception test results show that the identification of vowels preceding deleted $/ \mathrm{s} /$ as a noun or adjective plural or a second person singular verb marker is very difficult for the Granada participants, as well as for the Cartagena participants. Despite the high alternation for /e/, participants identified items with /e/ before final /-s/ at a rate of only $38.45 \%$, whereas, Cartagena participants identified items with /e/ before deleted final /-s/ at a rate of $35.57 \%$. The phonetic variation of the allophone $[\varepsilon]$ before deleted post-nuclear/s/ does not necessarily make its identification easier. Thus, this observed degree of alternation is not sufficient to constitute a conclusive phonemic distinction. Granada Spanish speakers do not receive sufficient acoustic cues within this alternation to qualitatively distinguish between a vowel preceding deleted /s/ and a vowel without a following /s/. In accordance with the notions of Iverson and Kuhl (1995), the Spanish open allophone $[\varepsilon]$ of the phoneme /e/ is very close to the closed allophone [e], which is the phonetic prototype within the listener's perceptual space, and therefore, is considered as another instance of the vowel /e/. For instance, the word peso 'weight' whether pronounced with an open /e/ as in ['pe.so] or a closed /e/ as in ['pe.so] would still be understood as peso. Sebastián et al. (1999) found that native speakers of Spanish who acquired Catalan after three years of age were unable to distinguish between instances of /e/ and $/ \varepsilon /$, whereas native speakers of Catalan had no trouble in doing so. They concluded that the individuals who acquired Catalan after the first year of age have lost the capacity to perceive the phonetic difference between the closed and open allophones of /e/. Results in this study, therefore, do not support Salvador's (1977) observation that in certain limited contexts native speakers use alternations in vowel quality to make semantic or morphological distinctions.

The objective of this study was to investigate the existence and extension of tense-lax vocalic alternation and to verify its functional role in Granada Spanish. Although vowel alternation was assessed for this variety as well as for Cartagena Spanish, its functional role is not supported for either dialect. Although the Spanish vowel system is regarded as relatively 
simple with five phoneme vowels, the phonetic variation they undergo is great. Acoustic measurements show that vowels display change in timbre or quality throughout the acoustic space in which they are articulated. However, it seems the case that no matter how great a vowel alternation can be, perceptually-wise, listeners only recognize five vowels.

\section{REFERENCIAS BIBLIOGRÁFICAS}

Alarcos Llorach, Emilio. 1958. Fonología y fonética (a propósito de las vocales andaluzas). Archivum 8.193-205.

Alvar, Manuel. 1955. Las hablas meridionales de España y su interés para la lingüística comparada. Revista de Filología Española 39: 284-313.

Becerra, Servio. 1985. Fonología de las consonantes implosivas en el español urbano de Cartagena de Indias (Colombia): ensayo socio-lingüístico. Bogotá: Instituto Caro y Cuervo.

Boersma, Paul and David Weenink. 2014. Praat: doing phonetics by computer (version 5.3.61) [computer program]. Retrieved February, 2014 from http:www.praat.org/

CARLSON, KRISTIN M. 2006. An acoustic and perceptual analysis of compensatory processes in vowels preceding deleted post-nuclear/s/in Andalusian Spanish. West Lafayette, IN: Purdue University MA thesis.

Figueroa, Neysa. 2000. An acoustic and perceptual study of vowels preceding deleted postnuclear /s/ in Puerto Rican Spanish. Hispanic linguistics at the turn of the millennium: papers from the 3rd Hispanic linguistics symposium, ed. by Héctor Campos, Elena Herburger, Alfonso Morales-Front, and Thomas J. Walsh, pp. 66-79. Somerville, MA: Cascadilla Press.

Hammond, Robert M. 1978. An experimental verification of the phonemic status of open and closed vowels in Spanish. Corrientes actuales en la dialectología del Caribe hispánico: actas de un simposio, ed. by Humberto López Morales, pp. 93-143. Puerto Rico: Editorial Universitaria, Universidad del Puerto Rico.

IBM CoRp. ReLEASEd 2012. IBM SPSS Statistics for Windows, Version 21.0. Armonk, NY: IBM Corp.

IVERSON, P., AND P. K. KuHL (1995). Mapping the perceptual magnet effect for speech using signal detection theory and multidimensional scaling. Journal of the Acoustical Society of America. 97: 553-562.

Johnson, KeIth. 2003. Auditory and acoustic phonetics. Oxford: Wiley-Blackwell.

Ladefoged, Peter. 2001. Vowels and consonants. Oxford: Wiley-Blackwell.

LabOV, William. 1984. Field methods of the Project on Linguistic Change and Variation. In J. Baugh \& J. Sherzar (eds.). Language in Use, pp. 43-70. Englewood Cliffs: Prentice Hall.

Llisterri, Johquim, y Dolors Poch. 1987. Análisis acústico del timbre vocálico en las realizaciones normativas del plural en andaluz oriental. Revista Española de Lingüística 17: 185.

López Morales, Humberto. 1984. Desdoblamiento fonológico de las vocales en el andaluz oriental: reexamen de la cuestión. Revista Española de Lingüística 14.85-97.

Matlab Versión 7.13 Natick. Massachusets: The MathWorks Inc., 2011. 
Martínez Melgar, Antonia. 1986. Estudio experimental sobre un muestreo de vocalismo andaluz. Estudios de Fonética Experimental 2: 197-248.

1994. El vocalismo del andaluz oriental. Estudios de Fonética Experimental 6.13-64.

MondÉJAR Cumpián, JosÉ. 1970. Diacronía y sincronía en las hablas andaluzas. Lingüística Española Actual 1: 375-402.

Navarro Tomás, Tomás. 1939. Desdoblamiento de fonemas vocálicos. Revista de Filología Hispánica 1: 165-167.

RonQuest, ReBeCCA E. 2012. An acoustic analysis of heritage Spanish vowels. Bloomington, IN: Indiana University dissertation.

SAlVAdOR, Gregorio. 1977. Unidades fonológicas vocálicas en andaluz oriental. Revista Española de Lingüistica 7: 1-23.

SAnders, Benjamin Patric. 1994. Andalusian vocalism and related processes. Urbana, IL: University of Illinois at Urbana-Champaign dissertation.

Sebastián, N., L. Bosch y A. Acosta. 1999. La percepción del habla. En de Vega, M. y Cuetos, F. (eds.) Psicolingüistica del español, pp. 53-88. Madrid: Trotta.

\section{APPENDix A}

Figure 1. Labeling of utterance-final /e/ in the word ves 'you see'

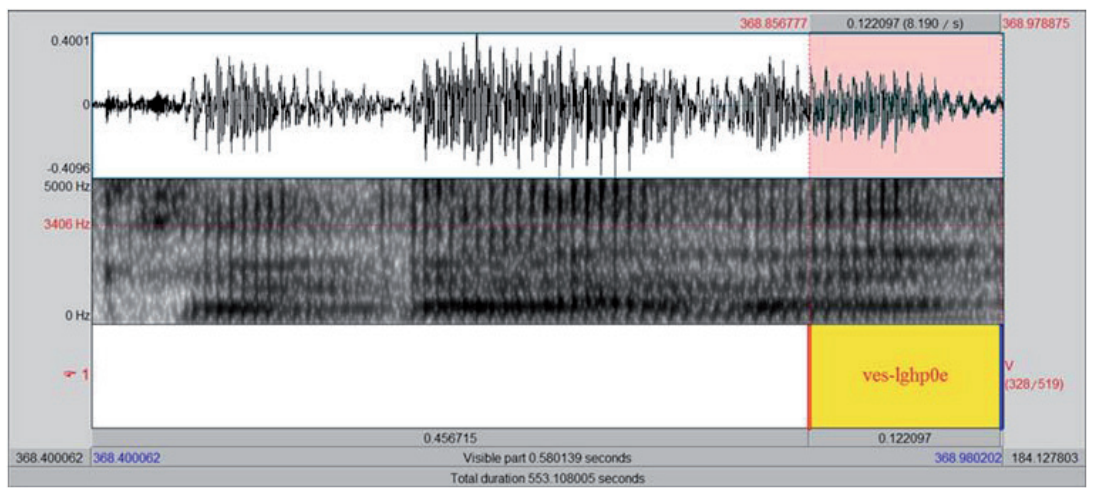


Figure 2. Vowel Alternation in Granada

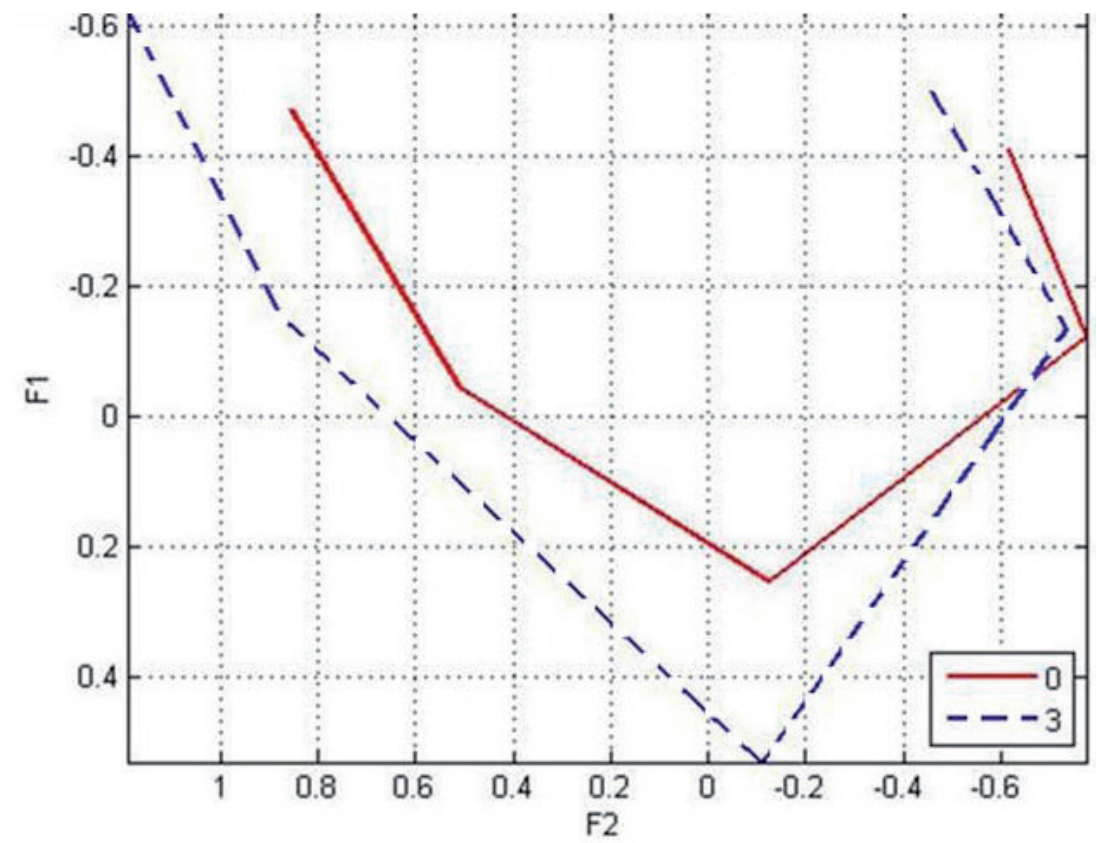

Figure 3. Vowel Alternation in Cartagena

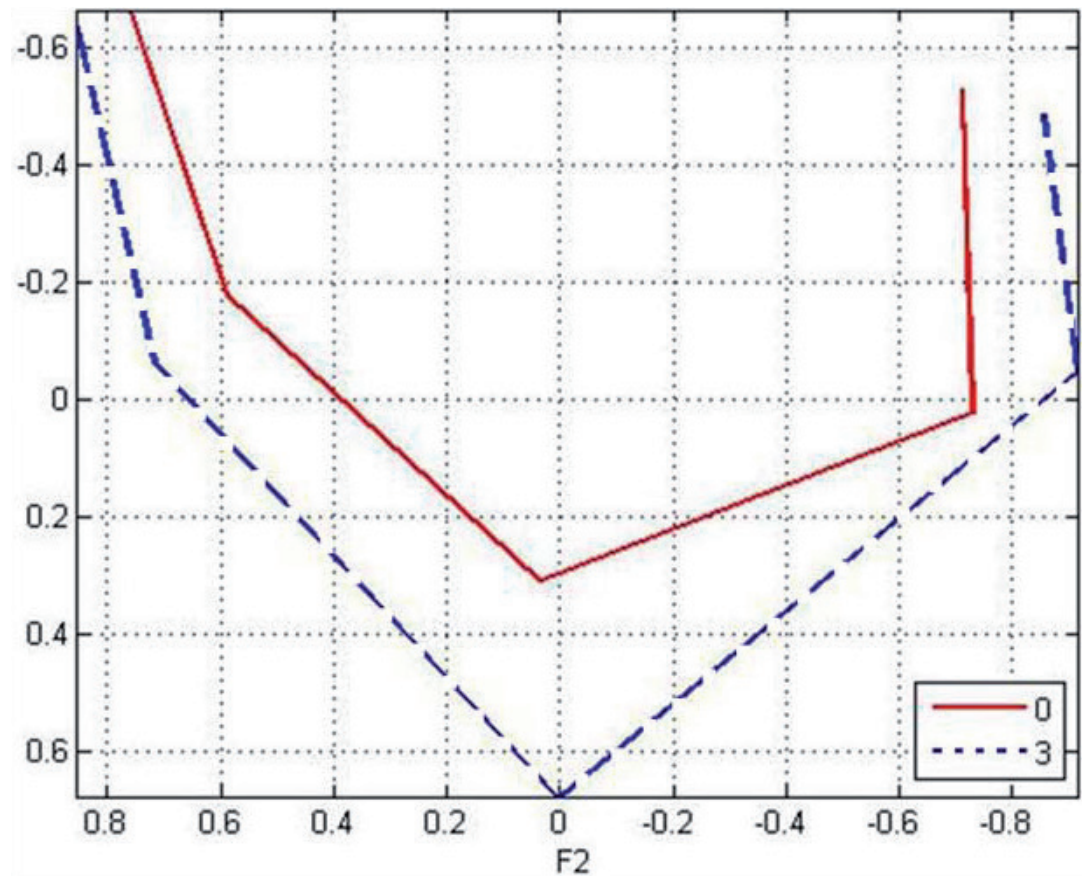




\section{Appendix B}

Table 1. Paired Sample t-test

\begin{tabular}{|c|c|c|c|c|c|c|c|c|}
\hline & \multicolumn{6}{|c|}{ Paired Differences } & & \multirow{3}{*}{$\begin{array}{l}\text { Sig. } \\
\text { (2-tailed) }\end{array}$} \\
\hline & \multirow[b]{2}{*}{ Mean } & \multirow{2}{*}{$\begin{array}{c}\text { Std. } \\
\text { Deviation }\end{array}$} & \multirow{2}{*}{$\begin{array}{c}\text { Std. Error } \\
\text { Mean }\end{array}$} & \multicolumn{2}{|c|}{$\begin{array}{l}95 \% \text { Confidence } \\
\text { of the Difference }\end{array}$} & \multirow[b]{2}{*}{$\mathrm{t}$} & \multirow[b]{2}{*}{$\mathrm{df}$} & \\
\hline & & & & Lower & Upper & & & \\
\hline $\begin{array}{c:c}\text { Pair } 1 \text { Items without/s/- } \\
\\
\text { Items with/s/ } \rightarrow[\varnothing]\end{array}$ & 48.73400 & 11.63445 & 1.83957 & 45.01312 & 52.45488 & 26.492 & 39 & .000 \\
\hline
\end{tabular}

\section{Analysis of VARiance (ANOVA)}

Between-Subjects Factors

\begin{tabular}{|ll|l|}
\hline & & $\mathrm{N}$ \\
\hline Vowel & 1.0 & 40 \\
& 2.0 & 40 \\
& 3.0 & 40 \\
Dialect & 1 & 60 \\
& 2 & 60 \\
\hline
\end{tabular}

Tests of Between-Subjects Effects Dependent variable percent

\begin{tabular}{|l|c|c|c|c|c|}
\hline Source & $\begin{array}{c}\text { Type III Sum } \\
\text { of Squares }\end{array}$ & df & Mean Square & F & Sig. \\
\hline Corrected Model & $2240.942^{\mathrm{a}}$ & 5 & 448.188 & 1.367 & .242 \\
Intercept & 181596.870 & 1 & 181596.870 & 553.698 & .000 \\
Vowel & 1259.978 & 2 & 629.989 & 1.921 & .151 \\
Dialect & 792.434 & 1 & 792.434 & 2.416 & .123 \\
Vowel * Dialect & 188.530 & 2 & 94.265 & .287 & .751 \\
Error & 37388.693 & 114 & 327.971 & & \\
Total & 221226.505 & 120 & & & \\
\hline Corrected Total & 39629.635 & 119 & & & \\
\hline
\end{tabular}

a. R Squared $=.057$ (Adjusted R Squared $=.015)$ 


\section{Estimates}

Dependent Variable: Percent

\begin{tabular}{|c|c|c|c|c|}
\hline \multirow{2}{*}{ Vowel } & \multirow{2}{*}{ Mean } & Std. Error & Lower Bound & Upper Bound \\
\cline { 4 - 5 } & & 2.863 & 29.578 & 40.922 \\
\hline$[\mathrm{a}]$ & 35.250 & 2.863 & 32.656 & 44.001 \\
\hline$[\mathrm{e}]$ & 38.329 & 2.863 & 37.453 & 48.797 \\
\hline$[\mathrm{o}]$ & 43.125 & & \\
\hline
\end{tabular}

\section{Pairwise Comparisons}

Dependent Variable: Percent

\begin{tabular}{|c|c|c|c|c|c|c|}
\hline \multirow[t]{2}{*}{$\begin{array}{c}\text { (I) } \\
\text { Vowel }\end{array}$} & \multirow[t]{2}{*}{$\begin{array}{c}(\mathrm{J}) \\
\text { Vowel }\end{array}$} & \multirow[t]{2}{*}{$\begin{array}{c}\text { Mean Difference } \\
(\mathrm{I}-\mathrm{J})\end{array}$} & \multirow[t]{2}{*}{ Std. Error } & \multirow[t]{2}{*}{ Sig. ${ }^{a}$} & \multicolumn{2}{|c|}{$\begin{array}{c}95 \% \text { Confidence Interval } \\
\text { for Difference }^{\mathrm{a}}\end{array}$} \\
\hline & & & & & Lower Bound & Upper Bound \\
\hline \multirow[t]{2}{*}{ [a] } & [e] & -3.079 & 4.050 & 1.000 & -12.918 & 6.761 \\
\hline & [o] & -7.875 & 4.050 & .163 & -17.715 & 1.965 \\
\hline \multirow[t]{2}{*}{ [e] } & [a] & 3.079 & 4.050 & 1.000 & -6.761 & 12.918 \\
\hline & [o] & -4.796 & 4.050 & .716 & -14.636 & 5.043 \\
\hline \multirow[t]{2}{*}{ [o] } & [a] & 7.875 & 4.050 & .163 & -1.965 & 17.715 \\
\hline & [e] & 4.796 & 4.050 & .716 & -5.043 & 14.636 \\
\hline
\end{tabular}

Based on estimated marginal means

a. Adjustment for multiple comparisons: Bonferroni.

\section{Univariate Tests}

Dependent Variable: Percent

\begin{tabular}{|c|c|c|c|c|c|}
\hline & Sum of Squares & df & Mean Square & F & Sig. \\
\hline Contrast & 1259.978 & 2 & 629.989 & 1.921 & .151 \\
\hline Error & 37388.693 & 114 & 327.971 & & \\
\hline
\end{tabular}

The F tests the effect of Vowel. This test is based on the linearly independent pairwise comparisons among the estimated marginal means. 


\section{Vowel * Dialect}

Dependent Variable: Percent

\begin{tabular}{|c|c|c|c|c|c|}
\hline \multirow[b]{2}{*}{ Vowel } & \multirow[b]{2}{*}{ Dialect } & \multirow[b]{2}{*}{ Mean } & \multirow[b]{2}{*}{ Std. Error } & \multicolumn{2}{|c|}{ 95\% Confidence Interval } \\
\hline & & & & Lower Bound & Upper Bound \\
\hline \multirow[t]{2}{*}{1.0} & 1 & 39.000 & 4.050 & 30.978 & 47.022 \\
\hline & 2 & 31.500 & 4.050 & 23.478 & 39.522 \\
\hline \multirow[t]{2}{*}{2.0} & 1 & 39.163 & 4.050 & 31.141 & 47.185 \\
\hline & 2 & 37.494 & 4.050 & 29.472 & 45.517 \\
\hline \multirow[t]{2}{*}{3.0} & 1 & 46.250 & 4.050 & 38.228 & 54.272 \\
\hline & 2 & 40.000 & 4.050 & 31.978 & 48.022 \\
\hline
\end{tabular}

Post Hoc Tests

\section{Multiple Comparisons}

Dependent Variable: Percent Tukey HSD

\begin{tabular}{|c|c|c|c|c|c|c|}
\hline \multirow{2}{*}{$\begin{array}{c}(\mathrm{I}) \\
\text { Vowel }\end{array}$} & \multirow{2}{*}{$\begin{array}{c}(\mathrm{J}) \\
\text { Vowel }\end{array}$} & \multirow{2}{*}{$\begin{array}{c}\text { Mean } \\
\text { Difference (I-J) }\end{array}$} & \multirow{2}{*}{ Std. Error } & \multirow{2}{*}{ Sig. } & \multicolumn{2}{|c|}{$\begin{array}{c}95 \% \text { Confidence } \\
\text { Interval }\end{array}$} \\
\hline & & & & & $\begin{array}{l}\text { Lower } \\
\text { Bound }\end{array}$ & $\begin{array}{l}\text { Upper } \\
\text { Bound }\end{array}$ \\
\hline \multirow[t]{2}{*}{ [a] } & {$[\mathrm{e}]$} & -3.0788 & 4.04951 & .728 & -12.6952 & 6.5377 \\
\hline & [o] & -7.8750 & 4.04951 & .131 & -17.4914 & 1.7414 \\
\hline \multirow[t]{2}{*}{ [e] } & [a] & 3.0788 & 4.04951 & .728 & -6.5377 & 12.6952 \\
\hline & [o] & -4.7962 & 4.04951 & .465 & -14.4127 & 4.8202 \\
\hline \multirow[t]{2}{*}{ [o] } & [a] & 7.8750 & 4.04951 & .131 & -1.7414 & 17.4914 \\
\hline & {$[\mathrm{e}]$} & 4.7962 & 4.04951 & .465 & -4.8202 & 14.4127 \\
\hline
\end{tabular}

Based on observed means.

The error term is Mean Square(Error) $=327.971$. 